\title{
Harnessing new models of care for chronic disease: co-design and sustainable implementation of group clinics into UK clinical practice
}

\author{
Authors: Fraser Birrell, ${ }^{\mathrm{A}, \mathrm{B}}$ Iain Goff, ${ }^{\mathrm{B}}$ Liz Coulson, ${ }^{\mathrm{B}}$ Tania Jones, ${ }^{\mathrm{B}}$ Wasim Baqir, ${ }^{\mathrm{C}}$ Nicola O'Brien, ${ }^{\mathrm{D}}$ Tim Rapley, \\ Keith Gray, ${ }^{F}$ Brian Flood $^{G}$ and Michele Russell-Westhead ${ }^{A, H}$
}

\section{Aims}

$>$ Demonstrate group clinics can be sustainably implemented in UK primary and secondary care.

$>$ Identify enabling themes and promoting factors to support scaling up.

> Show efficacy and efficiency, compared with usual care.

\section{Methods}

\section{Mixed methods}

Prospective observational cohort study, qualitative focus groups and interviews plus a non-inferiority randomised controlled trial in osteoporosis: primary outcome measure - mean possession ratio of bisphosphonates over 12 months.

Group clinics studied:

$>$ mixed early and chronic inflammatory arthritis group clinics in two community hospitals 2010-17

> pharmacy-led osteoporosis group clinics in three general practices 2012-13

> early arthritis group clinic at one further community hospital, 2016-17. Thematic analysis on inflammatory arthritis $(n=15)$ triangulated with patients attending primary care osteoporosis group clinics $(n=11)$

\section{Results}

Two-thousand four-hundred and ninety-eight patient attendances for both early and chronic inflammatory arthritis at 145 group

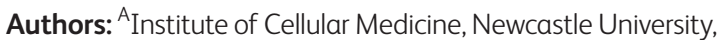
Newcastle upon Tyne, UK; ${ }^{\mathrm{B}}$ Rheumatology, Northumbria Healthcare NHS Foundation Trust, Newcastle upon Tyne, UK; ${ }^{\text {P Pharmacy, }}$ Northumbria Healthcare NHS Foundation Trust, Newcastle upon Tyne,

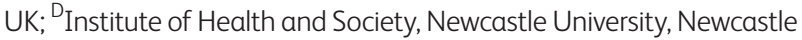
upon Tyne, UK; ESocial Work, Education and Community Wellbeing, Northumbria University, Newcastle upon Tyne, UK; ${ }^{F}$ Research and Development, Northumbria Healthcare NHS Foundation Trust, Newcastle upon Tyne, UK; ${ }^{G}$ Patient representative, Northumbria Healthcare NHS Foundation Trust, Newcastle upon Tyne, UK; ${ }^{\mathrm{H}} \mathrm{Clinical}$ Education, Northumbria University, Newcastle upon Tyne, UK

\section{Table 1. Five main enabling themes}

\begin{tabular}{|c|c|c|}
\hline $\begin{array}{l}\text { Enabling } \\
\text { theme }\end{array}$ & Details & $\begin{array}{l}\text { Impact on } \\
\text { patient care and } \\
\text { satisfaction }\end{array}$ \\
\hline Efficiency & $\begin{array}{l}\text { Reduced waiting times } \\
\text { More streamlined } \\
\text { administration } \\
\text { More effective use of } \\
\text { time }\end{array}$ & $\begin{array}{l}\text { 'It's very helpful } \\
\text { and if there's } \\
\text { anything that you're } \\
\text { concerned about, } \\
\text { it's easier than } \\
\text { waiting ... for an } \\
\text { appointment.' }\end{array}$ \\
\hline Empathy & $\begin{array}{l}\text { Shared problems } \\
\text { Shared understanding } \\
\text { Group support }\end{array}$ & $\begin{array}{l}\text { 'We are all in the } \\
\text { same boat.' }\end{array}$ \\
\hline Education & $\begin{array}{l}\text { Learning from team } \\
\text { Learning from peers }\end{array}$ & $\begin{array}{l}\text { 'I've got a much } \\
\text { better understanding } \\
\text { of how my disease } \\
\text { works.' }\end{array}$ \\
\hline Engagement & $\begin{array}{l}\text { 'Appropriate' } \\
\text { personality, benefits of } \\
\text { a trained educator } \\
\text { Individualisation in a } \\
\text { group setting } \\
\text { Positive physical and } \\
\text { emotional environment }\end{array}$ & $\begin{array}{l}\text { 'Well he's very good } \\
\text { in that he talks to } \\
\text { the group, but also } \\
\text { he acknowledges } \\
\text { that you're an } \\
\text { individual.' } \\
\text { 'You can have a } \\
\text { laugh, and it's more } \\
\text { relaxed and you } \\
\text { probably get a bit } \\
\text { more out of this } \\
\text { than you do from a } \\
\text { one to one.' }\end{array}$ \\
\hline Empowerment & $\begin{array}{l}\text { Agency, autonomy, } \\
\text { advocacy } \\
\text { Focus on personal } \\
\text { impact } \\
\text { Promoting behavioural } \\
\text { change - physical } \\
\text { wellbeing }\end{array}$ & $\begin{array}{l}\text { 'It's made me } \\
\text { realise I am not that } \\
\text { badly off but need } \\
\text { to take more control } \\
\text { so not to get worse.' }\end{array}$ \\
\hline
\end{tabular}


clinics at two hospitals and 45 early inflammatory arthritis patients attending group clinics at a third hospital. A mean of 17 patients attended each mixed group clinic (rising from 15 in 2010-11 to 18 in 2016 and 20 in 2017) and reported very high satisfaction (median 10/10, interquartile range 9-10,10). Seven-hundred and ninety-four $(40 \%)$ of 2,009 patients with disease activity score (DAS) data reached low disease activity (DAS <3.2) or remission (DAS <2.6). In the early arthritis cohort, $82 \%$ of patients reached low DAS / remission and $57 \%$ reached remission by 6 months. Group clinics were implemented without additional resources beyond brief training on the job and were highly efficient for cost and quality.

Seventy-five patients attended one of four 90 -minute primary care osteoporosis group clinics. Eighty-three attended usual care for a 1:1 appointment lasting 15 minutes. Ten-year fracture risk for major osteoporotic/hip fracture was $26 / 14 \%$ for group and $23 / 10 \%$ for usual care. Mean possession ratio was 0.62 for group and 0.54 for usual care (confirmed as non-inferior). All three models delivered 200-300\% efficiency for the same or better outcomes compared to usual care.
Qualitative data analysis identified five main enabling themes: efficiency, empathy, education, engagement and empowerment (Table 1). Five promoters to translate these themes into clinical practice were articulated: prioritisation, personalisation, participation, pedagogical approach and personality.

\section{Conclusion}

Group clinics are a sustainable, clinically effective and efficient method for chronic disease care in the UK and can be led by different clinicians after brief training on the job. By engaging patients in co-design and evaluation, robust, patient-centred models have been implemented and enabling themes and promoting factors have been identified. These can be used to support the delivery of effective training for clinicians for chronic disease group clinics as a routine care option in both primary and secondary care.

\section{Conflict of interest statement}

None declared. 